\title{
INTELLIGENCE CAPITAL
}

\section{Maid Pajević ${ }^{1}$}

UDC 005.336.4

005.94

Agency for Education and Professional Training, Ministry of Security of Bosnia and Herzegovina

Received: 16.05.2011

Accepted: 02.07.2011

\begin{abstract}
The author of this article presents a new theoretical concept of intelligence capital, with which he explains the multi-meaningful term 'intelligence'. The author offers a conceptual frame, ,intelligence capital “ as a generic complex consisting of four interactively linked elements. The contribution of this article is, among other things, an answer to a question: What is an applicative value of intelligence capital as a new theoretical concept for the system of security and intelligence of BiH? Historical context implies greater responsibility of OSA BiH in realising its preventive function of protecting security of $\mathrm{BiH}$ and its citizens. Theoretical frame of the intelligence capital implies that the system of security and intelligence of BiH should be able to respond to strategic questions: to know-what, to know - why, to know - how, to know - who.
\end{abstract}

Key words: security, intelligence service, intelligence activity, intelligence product and intelligence capital.

\section{INTRODUCTION}

The existing literature, discussions, studies and articles offer divergent understandings in using the term intelligence and its substance. It is a common case that only legal or political substance of this term is used, while historic or sociological dimension is omitted, and vice versa. That leads to a partial and one-sided approach to analysis and research, which, in turn, influences social practice. Therefore, owing to its unbalanced use, various difficulties and misunderstandings are encountered in both, theoretical scientific and practical sphere.
In accordance with previously stated understanding of intelligence, it could be said that there is no widely accepted definition or interpretation of this multidimensional term.

1 Correspodence to:

Maid Pajević, PhD, Agency for Education and Professional Training, Ministry of Security of Bosnia and Herzegovina

Muje Bjelavca 5 D, 88000 Mostar

Phone: +38761106023

E-mail: m.pajevic@bih.net.ba 
Owing to the ideas, understandings and concepts of the authors such as Maslesa (2001), Dedijer (2000 and 2002), Waltza (2003), Culahović (2008), Žuljević (2006), Pulić and Sundać (1998), Bilandžić (2008), Sims (2009) and Krizan (1999), we shall present the concept of intelligence capital with which we could also explain the multi meaningful term of intelligence.

The term intelligence has been introduced in this essay as a neologism, which is called intelligence capital. Capital is "an economic term for tools that improve human abilities to do the work" (Ćulahović, 2008, p. 151).

For the studies of intelligence, the subject of study is intelligence capital; its obverse could be found in economic terminology as intellectual capital. Pulić and Sundać (1998, p. 88) elaborated on the term of intellectual capital by making a composition of three important components: ,(1) human capital - abilities, knowledge, skills and experience of a company's employees and managers, dynamics of intelligent organisation's acting in applying competitive surrounding; (2) structural capital - support to infrastructure of human capital, which includes a system of information technology, corporation image, owner's data bases, organisational concepts, documents, patents, licences and copyrights; (3) consumers' capital interaction between a company and its clients".

Within the studies of intelligence, we offer a conceptual frame of 'intelligence capital', which represents a generic complex composed of four interactively linked elements:

- Organisation as a bearer of intelligence activity

- Intelligence activity that is being developed in intelligence process

- Final intelligence product as a result of intelligence process, an

- Value of a final intelligence product in socio-political process (feedback

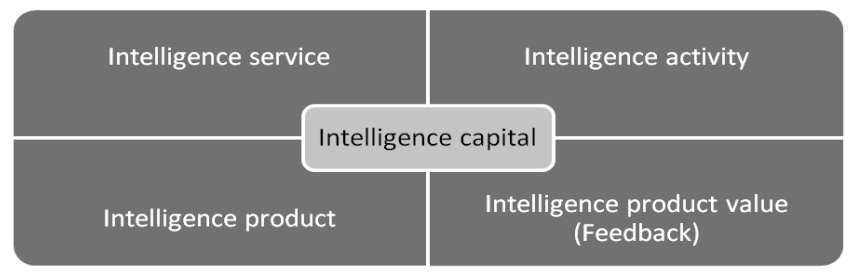

Figure 1. Scheme: Components of intelligence capital

\section{INSTITUTIONAL INTELIGENCE CAPITAL}

In order to understand a role of the concept of intellectual capital in socio-political, economic, cultural, social and intellectual sense, we will point a few essential characteristics. Decisions to undertake intelligence activity could be international, national (initiated by a state), non-governmental, business and individual, which implies that a state does not have a monopoly over intelligence activity. Therefore, a synonymous for private (business) intelligence capital would be business intelligence. In all stated cases, creation of new intelligence capital is conditioned by appropriate investments. Intelligence capital, be it in institutionalized state form or a private sector, always works for prosperity of a state (ex. economic prosperity, state and citizens' security, etc.)

Modern intelligence exceeded its traditional frame (informing its final users) both, in a content of its activities and in forms and methods of work. Intelligence services today direct their activities with an aim to change relations and situation in certain states and geographical regions (special war, some forms of subversive activity, such as propaganda, political, economic and other pressures, coup, conspiracies and others). Therefore, it is obvious that intelligence and intelligence activity, in a new security environment, under the influences of evolutive trends and determinants have gone through a change. It is important to note that intelligence is a rather wide term, wider than intelligence service, which we perceive as an institution within a state and political apparatus. 
This transformation occurred owing to the fact that it is more simple, nowadays, to obtain intelligence data through various official, semi-official (private and state-owned) organisations and institutions (scientific and technical, economic, financial, commercial and some international), which are, by the nature of their basic activities, suitable for gathering various intelligence data.

Shulsky and Smith (2002) also explain intelligence service as an "organisation" that conducts the above mentioned activities. One of the prominent characteristics of such an organisation is secrecy, with which their activities have to be performed. Many of the methods, such as using secret agents or applying strict rules regarding access to information, stem from these requirements. Intelligence services have informative function, which means supplying information to external users. Intelligence services are responsible for conducting undercover activities in order to bring benefits to governmental foreign political goals. Therefore, a necessary component of intelligence activity is undercover operations.

\section{INTELIGENCE CAPITAL AS AN ACTIVITY}

Intelligence capital is created with intelligence process. The process of intelligence capital production depends on investing in physical, human, social and cultural capital. The fact is that intelligence capital begins with a specific intelligence process; it is distinguished from all other resources. Distribution of intelligence capital in a form of a final intelligence product, according to the legally and methodologically defined standard procedure of intelligence, enables final users to achieve efficient results in a certain social field of activity (politics, army, justice, police, etc.)

Shulsy and Smith (2002, p. 2), regard a term intelligence activity as gathering and an analysis of intelligence information. Also, they regard "activities" as undertaking intelligence and counter-intelligence activities aimed at the adversary, in order to prevent an access to protected and relevant information, using a wide range of methods (ex. deceiving an adversary, etc.)

Therefore, intelligence has a wide range of activities, such as various methods of collecting data (ex. espionage, photographing from the air, wiretapping, researching public documents, radio, TV, internet...). Also, various techniques for analysing collected data are a part of it.

Some of these techniques could be similar to methods used in social sciences, while some other are used to decipher coded messages typical for the world of intelligence. Misinforming others includes various activities as well. Some of those are similar to the work of crime services, such as research and having foreign intelligence agents as suspects. In that way, it is possible to gain various types of knowledge about their activities. Other methods are more esoteric, such as using codes for protection of communications (although current moment in a development of information technology makes coded capacities commercially available). There are various means for deceiving opponents, such as operations of double agents, false messages that lead an adversary, after being intercepted, to false conclusions, after having believed in them. All the listed activities have to make the adversary form a false conclusion or withhold information.

Therefore intelligence activity could be defined as a component of a fight between opponents, which is, in particular, based on information (ex. economic competitiveness, diplomatic manoeuvring or negotiations, or a threat, or a use of military) (Shulsky and Smith, 2002).

\section{INTELIGENCE CAPITAL AS A PRODUCT}

Shulsky and Smith (2002) define term intelligence as information relevant for governmental policy making and implementing, in order to improve national security interests and face threats of actual or potential adversaries. 
Intelligence information usually includes not only unprocessed data collected by means of espionage or any other means, but also their analysis or evaluation, which leads to results. This result is often interpreted as an intelligence product, which, as a rule, represents an immediate value for policy makers. Breadth, for which this intelligence product strives, consists of presenting and overall evaluation of a situation, based on all available data, public as well as secret one, in various ways, depending on every intelligence service.

From the Scheme 2 we can conclude that in the first phase of intelligence research, data is collected from surrounding. In the next phase of analysis and production, the information converts to intelligence information. In that sense, Prunckun (2010, p. 2) emphasises: "information is unrefined raw material, which is used for a production of final, focused intelligence information. Without information there is no intelligence information."

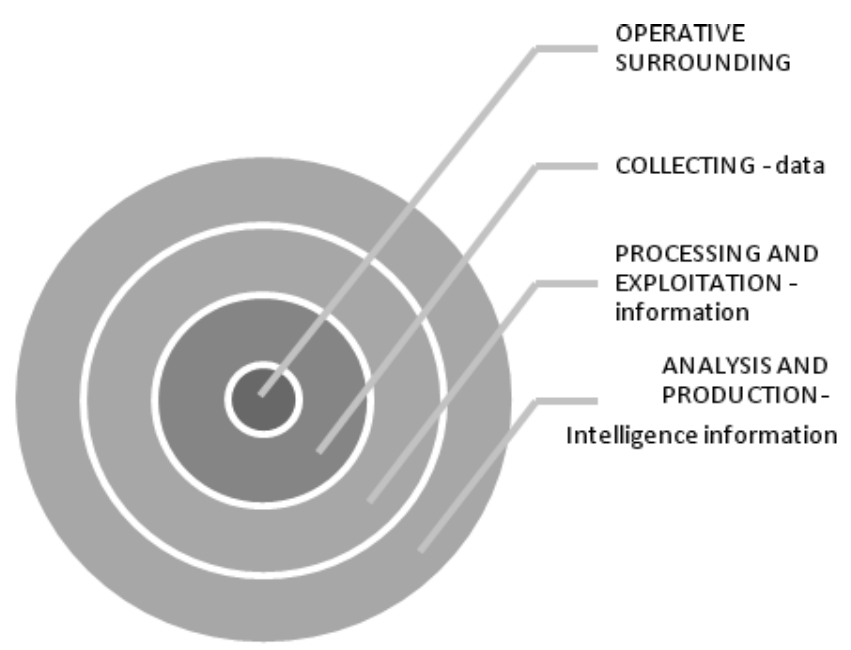

Figure 2. Scheme: Relation between the phase of intelligence process and intelligence product

Waltz (2003) presents a distinction between three levels of abstract knowledge, where each of previously stated could be presented as intelligence in forms according to different levels: from an unprocessed report to a final intelligence product. Information is individual observation, measurement and a message, which comes from the lowest level (human communication, text messages, and scientific instruments are an important source of data).
Information is an organised set of data. Organised process could include: selecting, classification, or indexing and integrating information, where information is stored in one place according to defined elements in relation context, in order to provide easy search and analysis. Information which is analysed, understood and explained constitute knowledge or prediction (evaluation or prognosis). In that context, understanding information is defined as final intelligence product. Understanding information gives an extent of understanding of static and dynamic relations between subject data and ability to model a structure of past (and future) behaviour of those subjects. Knowledge includes static content and a dynamic process. According to Prunckun (2010) knowledge has criminal (police), business, military, and national security context.

To define intelligence information and separate it from ordinary information is not an easy task. The argument that supports that is that United Nations prefer milder term - military information rather than intelligence information (Herman, 1995, p. 372; Muller, 2004, p. 7). In a wider sense, intelligence information could be understood as processed information with an aim to support a receiver - decision maker. What converts information into intelligence information, is usually something perceived only by the eyes of the beholder.

In the security sense, intelligence information helps a receiver to identify threats, i.e. helps the receiver become aware of the necessity of undertaking certain timely political activity. Decision makers could perceive certain information as intelligence information, since it could serve their needs. However, others could perceive it as raw data or ordinary information (Müller-Wille, 2004).

According to this definition, secrecy and utilising hidden sources is not considered a prerequisite for intelligence information. Evaluation of open sources only could be categorised as intelligence information if created for a certain decision maker or if it helps a decision maker. However, if we focus on European intelligence cooperation and forming of European intelligence community, publicly available evaluations are not of primary importance. 
It is, rather, producing and exchanging confidential data between different national and European intelligence services.

"What makes information become intelligence information; it is defined by its origin. Intelligence information has to go through one of the institutions, which are considered to be official intelligence institutions.” (Müller-Wille, 2004, p. 7).

Intelligence capital as a final intelligence product is not a resource, which an intelligence services keeps in its database and, when needed, is created and delivered to policy makers or military officials. In that context, Grabo (2004, p. 4) emphasises: "Intelligence warning is not goods. A warning is not something that an analyst, intelligence community, a policy maker or a state have or do not have". The principle of quality suggests that intelligence, i.e. producers of intelligence product have to constantly strive to reach the highest possible level in their products. Quality of intelligence products is a matter of prestige for intelligence professionals in order to achieve and maintain credibility with intelligence consumers. In order to achieve the highest standard of quality, intelligence information has to be: early, timely, accurate, useful, complete, relevant, objective and available. "Strategic information gives advantage to its author, particularly in case when adversaries do not possess such information. In case of strategic information, their quantity is not as important as much as their quality." (Svete, 2006, p. 107).

Some countries have intentions to secure the influence of their own state in international relations. Intelligence service gives support to state and political leadership in evaluating some situation and making political decision in both domestic and foreign affairs. Here the question is not if intelligence capital would be forwarded to official levels of authority, but it is when it is going to be forwarded. Intelligence capital is a fresh product that assists political centres of power in decision making.

\section{VALUE OF INTELLIGENCE CAPITAL IN SOCIO-POLITICAL CONTEXT}

Intelligence capital is bit perfect. This idea corresponds to opinions of Dimitrijević and Stojanović (1979, p. 226) who stress that acknowledgement and understanding of complex reality that surrounds the subject of international affairs and people that make it, is not easy and it could be said that even the most developed and organised and the richest states in the world are not always, at every moment, entirely informed and aware of all the events in the world.

The most vital element of intelligence capital is its value in socio-political context. Intelligence capital has its temporal (long-term and short-term), spatial (outside and inside), symbolic (intelligence service and activity is founded on democratic principles and morals), and so-called intensity dimension (working in peace and at war), which, in cumulative way, determine its value. Therefore, the value of intelligence capital decreases in time if not used in contemporary socio-political, economic and other processes.

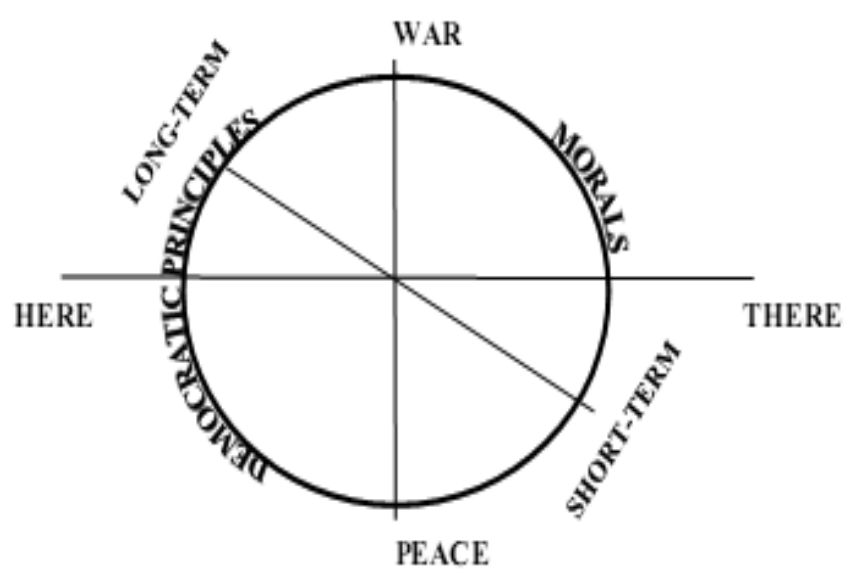

Figure 3. Scheme: Dimensions of intelligence capital

Source: Modified illustration by Steel (1995, p. 370), with added fourth symbolic dimension, which is presented in a shape of a circle (democratic principles and morals). 
Intelligence capital is productive since its usage augments a qualitative sum of users' results, which intelligence service could produce while providing consumers with privileged insight into specific security context. Intelligence capital has equipotent character.

Intelligence capital has informational power, which is based on the elements of a cognitive process: "data, information, knowledge and understanding" (Svete, 2006, p. 102). Endless appetites of a governing political system for intelligence capital that they use for achieving determined goals, made intelligence service more influential than other subjects in socio-political system. Intelligence information is not valuable if it does not result in defined intelligence capital. Intelligence capital, as a product, requires its practical use. Intelligence capital contributes to a decision making process and helps in directing and leading investigations organised and led by prosecutors and the police. Intelligence capital represents the essence of an activity and coordination process, and it has a great value at all levels of national decision making. Intelligence capital is used for implementation of police work led by intelligence information (i.e. intelligence-led policing). Also, intelligence capital has an influence on a decrease of crime.

The axiom of integrity implies intellectual integrity that needs to be a recognising point of intelligence service. That represents a crucial element for intelligence analyses and reporting, as well as a foundation on which the credibility is based in the eyes of an intelligence consumer.

The integrity requires adherence to facts and truthfulness with which these facts are interpreted and presented. Intelligence service officers need moral courage in order to be able to resist pressures and come to intelligence conclusions on the basis of facts.

Intelligence capital is generated and used in a sphere of so-called primordial ${ }^{2}$ dualism.

2 Lat. Primordialis, original, main, important (Anić, Klaić and Domović, 2002, p. 1158)
The term intelligence capital by itself is an oxymoron $^{3}$, i.e. a figure of speech (special sort of antithesis) in which two seemingly contradictory terms, in this case democracy (transparency) and secrecy are linked together. Modern democratic world is dedicated to modernising intelligence systems in accordance with democratic principles.

Since intelligence is productive and since its use is limited, it often earns returns. Return, which intelligence capital could earn is often an incentive for its creation. As a confirmation of this idea, Stelle (2006b, p. 26) says: „Information spends money, while intelligence (intelligence capital, author's remark) “.

Theoretical frame of intelligence capital implies that security-intelligence system of Bosnia and Herzegovina $(\mathrm{BiH})$ needs to give answers to strategic questions: to know-what, to know-why, to know-how, to know-who.

To know-what. This question focuses on obtaining knowledge on the basis of intelligence investigation, which has explorative, description, classificational, predictive and evaluative character regarding security issues for state/national security.

To know-why relates to knowledge of intelligence service regarding four goals that need to be achieved: explanation, understanding, evaluation and measuring influences of investigative security issues. All four goals stem from the role of intelligence service in security system. The function of intelligence service is realised in such a way to utilise all available sources allowed by law, and practically proven methods on informative-intelligence and preventivesecurity field in the sphere of prevention and repression of modern security threats, in cooperation with other subjects in the security-institutional frame on national and international level.

3 Grč. oxys sharp, bright, moros, thick, dim-witted; ret. spiritual stupidity; a thought which at first seems contradictory, yet both terms standing next to each other and being linked in a single term, ex. mute voice, loud secret, clever fool, eloquent silence, etc.. (Anić, Klaić i Domović, 2002, p. 979) 
To know-how implies that intelligence service gives answer to five research goals. That practically means that intelligence service first needs to classify research security questions, then explain them, understand them and foresee certain occurrences in the future, in order to intervene in efficient and effective way.

To know-how represents knowledge about recognising needs for organisational changes, which encompass three important elements: (1) a change, which is often a result of necessary adjustment of intelligence service to modern security challenges and organisational flaws that lead to scandals and disasters, (2) a size of a change implies dynamic change of structure, process and convictions, and (3) results of the change is a product of the intelligence service adaptation in relation to modern security surrounding (Zegart, 2007). Intelligence service has an evolutional character and points to all clearly evident changes and adjustments in its functional and organisational field. New security milieu is created by global, regional and national trends and challenges (ex. demographic trends, economic trends, growing energy needs, increase in unconventional threats such as terrorism, organised crime, proliferation of arms for mass destruction, etc.). All those presented security trends and occurrences made numerous states to undertake some of the mentioned evolutive measures, which represent a wide range of answers to a question "to know-how":

- modernise legislative frame in terms of harmonisation of domestic legislation, which encompasses intelligence sector with the EU recommendations,

- improve the intensity, level and mutual connection with users;

- adjust intelligence policy, programmes and plans with modern security policy and strategies,

- change of intelligence priorities and orientations in accordance with intelligence challenges,
- intensify offensive and defensive intensity and dynamics of action. Intelligence service never stands still; however, intensity of its activities could be greater or smaller,

- adjustment of organisation and structure in accordance with complexity of a problem,

- intensifying of a level of intelligence cooperation on both. domestic and international security-intelligence plan,

- significant modification and improvement of methods and means (with special regard to methods of cooperation, methods of analysis of all sources, as well as improvement and balanced use of open sources in analysis),

- use and adjustment to modern information technologies,

- employment of a greater number of professionals of various profiles,

- stimulation of staff to strive for academic titles and knowledge (ex. strategic intelligence activity, intelligence analysis, geo-strategy, geo-politics, etc.), intensify specialised and highly profiled training programmes,

- increase engagement of experts and scientists from other state and academic institutions,

- proclaim and fulfil democratic principles,

- develop relationships with business sector and civil society,

- revise security-intelligence culture,

- finding ways to keep intelligence professionals in intelligence services, since the process of intelligence maturity is a long one (similar to a process of precious pearl making) and losing those professionals represent a tremendous loss. It is also important to emphasise a necessity for creation of exit strategies in case of an excess of qualified professionals, in order to help them find alternative jobs or further education or training for different positions in other sectors, 
- managing intelligence services requires higher degree of education and professional training.

- Strengthening relations between intelligence service and civil sector, such as academic community, NGOs, citizens, etc. (Pajević, 2010, pp. 133-161).

To know-who is related to knowledge about a profile of a final intelligence product consumer. In that context, the question arises: What kind of intelligence capital is necessary to final consumers? Policy makers need to understand that the intelligence community provides answers, in timeframes, to posed questions. Intelligence service faces an imperative to become a relevant subject in political process.

\section{CONCLUSION}

In future, the greatest potential of intelligence capital will be adding "a new value" to intelligence report, which is a result of an intelligence process. Intelligence process is recognised by modern theoretical and practical understanding of intelligence capital and strategic knowledge management, which are directed to evaluation and prediction of current and future security occurrences.

Those are temporal dimensions, which exceeded traditional and standardised concepts of appraisal, and that is the essence of intelligence capital. Therefore, it is a crucial goal of the concept of intelligence capital to present a distinction between so-called bookkeeper's and market value of intelligence product, i.e. subjective (valorisation of intelligence product by intelligence service) and objective value of intelligence product (evaluation by final user/consumer). Intelligence capital enriches standard intelligence reports. Intelligence capital points to capability of intelligence service towards creation of a new value of intelligence product. Important functions of intelligence prod- uct are directed to provide support to political processes and preventive activities against modern security challenges.

The important characteristic of intelligence service is its relation with knowledge and its position towards dominant knowledge, which is prerequisite for "added value" of intelligence capital. Dominant knowledge is a kind of knowledge with which smaller social groups could bring the majority of society into subordinate position.

The value of intelligence capital is determined by two very important variables. The first one is a progressive variable based on the principle according to which intelligence encourages and strengthens inventiveness and imitativeness of human resources. Intelligence service with its inventive function invests significant means into training, education and science, with which prerequisites are created for individual and collective creativity, while with imitative function intelligence service is enabled to quickly and creatively overtakes knowledge of others, improves it and successfully use it, even better than those who invented them.

Such intelligence capital is distributed to final users in accordance with the principle "need to share". The other is destructive variable, which is created and encouraged by uninventive intelligence service. Such intelligence service creates intelligence capital with small or non-existent value. The other variable is a generator and creator of unusable intelligence potential, which means that intelligence service, as a bearer (organisation) of intelligence process (intelligence activity) creates intelligence product (intelligence data), which does not have applicative value and brings intelligence capital to its original level, so-called intelligence potential. 


\section{REFERENCES}

Anić, Š., Klaić, N., \& Domović, Ž. (2002). Rječnik stranih riječi. Zagreb, Croatia: Sani-plus.

Bilandžić, M. (2008). Poslovno-obavještajno djelovanje Business Intelligence u praksi. Zagreb, Croatia: AGM

Ćulahović, B. (2008). Ekonomija svijeta - rast, razvoj $i$ trendovi. Sarajevo, Bosnia and Herzegovina: Ekonomski fakultet.

Dedijer, S. (2000). Ragusa Intelligence \& Security (RIS) - A Model for the 21st Century!? [Electronic version]. National Security and Future, 1, 3-4. Retrieved Jule 20, 2008, from http://www.nsf-journal.hr/issues/v1_n3-4/dedijer.htm Dedijer, S. (2002). Development \& Intelligence 2003-2053, National Security and Future, 3, No 3 - 4.

Dimitrijević, V. \& Stojanović, R. (1979). Međunarodni odnosi: osnovi opšte teorije. (drugo izdanje). Beograd, Serbia: Nolit

Grabo, tM. C. (2004). Anticipating Surprise: Analysis for Strategic Warning. Lanham: University Press of America, Inc.

Krizan, L. (1999). Intelligence essentials for everyone [Electronic version]. Washington, D.C., Joint Military Intelligence College. Preuzeto Retrieved October 2, 2006, from http://www.scip.org/ krizan/IntelligenceEssentialsFull.pdf

Pajević, M. (2010). Uloga obavještajne službe u prevenciji savremenih sigurnosnih izazova. Nneobjavljena doktorska disertacija. University of Sarajevo. Fakultet za kriminalisti$\mathrm{ku}$, kriminologiju i sigurnosne studije.

Pulić, A. \& Sundać, D. (1998). Intelektualni kapital. Rijeka, Croatia: I.B.C.C.

Prunckun, H. (2010). Handbook of Scientific Methods of Inquiry for Intelligence Analysis. THE SCARECROW PRESS, INC. Lanham • Toronto • Plymouth, UK

Shulsky N., A., \& Schmitt, J., G. (2002). Silent Warfare: Understanding the World of Intelligence (Third Edition). Washington, D.C: Potomac Book, Inc.

Sims, E., J. (2009). Defending adaptive realism: Intelligence theory comes od age. In Gill, P.,

Steele, R. D. (2006). The Smart Nation Act: Public Intelligence in the Public Interest. Oakton, Virginia: OSS International Press.

Steele, R. D. (1995). Smart nations: national information strategies and virtual intelligence communities [Electronic version]. Paris: Open Source Solutions Group. Retrieved March 03, 2010, from http://www.oss.net/dynamaster/ file_archive/040320/70a2026f3edbc0e4f381074dde7cf88c/ oss1996-02-34.pdf

Svete, U. (2006). Strateški značaj informacijsko-komunikacijske tehnologije u savremenom međunarodnom okolišu. Polemos 9 (2), 101-117.

Waltz, E. (2003). Knowledge management int the intelligence enterprise. Boston - London: Artech House.
Zegart, A. (2007). Spying Blind: The CIA, the FBI, and the Origins of 9/11, Princeton University Press.

Žuljević, A. (2006) Ekonomija znanja i inovacije-šansa malih zemalja u globalizaciji, Zbornik radova 5 (9), Fakultet za poslovni menadžment, Univerzitet „Džemal Bijedic“" u Mostaru. 